\title{
Toxicity of nitric oxide and peroxynitrite to bacterial pathogens of fish
}

\author{
Juan J. Campos-Pérez ${ }^{1,2}$, Anthony E. Elliss ${ }^{1}$, Christopher J. Secombes ${ }^{2, *}$ \\ ${ }^{1}$ FRS Marine Laboratory, PO Box 101, Victoria Road, Aberdeen AB11 9DB, United Kingdom \\ ${ }^{2}$ Department of Zoology, University of Aberdeen, Tillydrone Avenue, Aberdeen AB24 2TZ, United Kingdom
}

\begin{abstract}
The inhibitory effect of the nitric oxide (NO) donor S-nitroso-acetyl-penicillamine (SNAP) and the $\mathrm{NO}$ and $\mathrm{O}_{2}^{-}$donor 3-morpholino-sydnonimine hydrochloride (SIN-1) was tested in a cell-free assay. Strains of the bacterial fish pathogens Aeromonas salmonicida, Renibacterium salmoninarum and Yersinia ruckeri were exposed to different concentrations of the NO donors for $24 \mathrm{~h}$. The results showed that NO possesses inhibitory properties, while peroxynitrite had no effect. However, when SIN-1 was used in combination with superoxide dismutase (SOD) alone or with catalase, an inhibitory effect comparable to that caused by SNAP was seen. The implications of these results are discussed.
\end{abstract}

KEY WORDS: SNAP $\cdot$ SIN-1 $\cdot$ Nitric oxide $\cdot$ Peroxynitrite $\cdot$ Renibacterium salmoninarum $\cdot$ Aeromonas salmonicida $\cdot$ Yersinia ruckeri

Resale or republication not permitted without written consent of the publisher

\section{INTRODUCTION}

In mammals, nitric oxide (NO) is produced by the action of a family of enzymes known as nitric oxide synthases (NOS). Two of the isoforms are expressed in endothelial (eNOS) and nervous (nNOS) tissue and have house-keeping roles such as cell-to-cell communication. The third isoform, inducible NOS (iNOS), is known to be expressed during immune responses against pathogens. The reactive nitrogen intermedi-

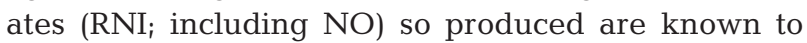
inhibit a range of pathogens such as viruses, bacteria, fungi, protozoans and helminths and also tumour cells (Clark \& Rockett 1996). However, NO can also combine with reactive oxygen species (ROS), particularly superoxide $\left(\mathrm{O}_{2}^{-}\right)$produced during the respiratory burst, to produce peroxynitrite, a more potent free radical (Ischiropoulos et al. 1992, Carreras et al. 1994). In mammalian NO research, cell-free assays have been used to investigate the inhibitory properties of NO and peroxynitrite to pathogens. Organisms such as Escherichia coli (Zhu et al. 1992, Brunelli et al. 1995),

${ }^{*}$ Corresponding author. E-mail: c.secombes@abdn.ac.uk
Mycobacterium avium (Doi et al. 1993), M. tuberculosis (O'Brien et al. 1994, Rhoades \& Orme 1997) and Staphylococcus aureus (Kaplan et al. 1996), the yeast Candida albicans (Vazquez-Torres et al. 1995, 1996), the protozoan Trypanosoma cruzi (Denicola et al. 1993), and the nematode Brugia malayi (Thomas et al. 1997) have been shown to be more susceptible to peroxynitrite than NO itself, whilst the opposite situation has been reported for the protozoan Leishmania major (Assreuy et al. 1994) and C. albicans (Fierro et al. 1996).

NO is a very versatile molecule, able to attack many enzyme targets such as cytochrome oxidases (Stuehr \& Nathan 1989), ribonucleotide reductase (Lepoivre et al. 1991), cytochrome P450 (Wink et al. 1993) and aldolase (Kahl et al. 1978). After $\mathrm{NO}$ combines with $\mathrm{O}_{2}{ }^{-}$to form peroxynitrite it can also attack enzymes with an iron-sulphur centre, such as hydrogenase (Hyman \& Arp 1991) and aconitase (Drapier \& Hibbs 1988). All these enzymes have important functions in the physiology of bacteria, parasites and tumour cells. However, this reactivity with enzymes makes NO potentially dangerous for the host cells and tissues. Indeed, NO and peroxynitrite have also been implicated in a series 
of non-infectious conditions such as cerebral ischaemia (Forman et al. 1998), acute myocardial infarction (Shimojo et al. 1998) and heart injury (Wang \& Zweier 1996). Moreover, endogenously produced peroxynitrite induces protein oxidation in the mitochondria and nucleus of immunostimulated macrophages (Szabo et al. 1997). Hence, it is not clear whether peroxynitrite formation is beneficial for the host even though it inhibits microbes.

In fish, NOS activity has been reported in several tissues (Schoor \& Plumb 1994, Sodestrom et al. 1995, Wong et al. 1998). Moreover, work by Neumann et al. (1995), Wang et al. (1995) and Neumann \& Belosevic (1996) has shown that a macrophage cell line and primary macrophage cultures from goldfish produce NO when stimulated with macrophage activating factor (MAF) and bacterial lipopolysaccharide (LPS). Wiegertjes et al. (1998) reported NO production in vitro by carp macrophages stimulated with LPS and with the intracellular parasite Trypanosoma borrelli. Buentello \& Gatlin (1999) also showed that medium composition exerts an influence in the NO production of channel catfish macrophages stimulated by LPS. The inducible form of NOS, iNOS, has been cloned and partially sequenced from a goldfish macrophage cell line and primary cultures of rainbow trout macrophages (Laing et al. 1999). Previous experiments have demonstrated that rainbow trout injected with Renibacterium salmoninarum showed an increase of NO (as measured by nitrite/nitrate concentration) in serum, and that iNOS is expressed in kidney and gill tissue (CamposPérez et al. 2000), suggesting that the produced NO may have a role in defence in this organism. Hence, in the present work the effectiveness of NO and peroxynitrite to inhibit strains of bacterial pathogens known to infect rainbow trout (Aeromonas salmonicida, R. salmoninarum and Yersina ruckeri) is assessed by using the NO donor S-nitroso-acetyl-penicillamine (SNAP) and the $\mathrm{NO}$ and $\mathrm{O}_{2}^{-}$donor 3-morpholino-sydnonimine hydrochloride (SIN-1) in a cell-free assay.

\section{MATERIALS AND METHODS}

Bacteria. The species and strains used were Aeromonas salmonicida MT 004 (A-layer negative and avirulent) and MT 423 (A-layer positive and virulent) (Sharp \& Secombes 1993); Renibacterium salmoninarum MT 426 (non-autoaggregating and avirulent), MT 405, MT 251 (non-autoaggregating, virulence unknown) and MT 1729 (autoaggregating and virulent) (Campos-Pérez 1998); and Yersinia ruckeri MT 223. All strains were obtained from the Marine Laboratory (Aberdeen) culture collection and grown on Tryptic soy agar (A. salmonicida and Y. ruckeri) or Mueller-
Hinton agar with L-cysteine ( $R$. salmoninarum). The $A$. salmonicida strains were stored in agar containing $10 \%$ glycerol at $-60^{\circ} \mathrm{C}$. Escherichia coli was grown in Tryptic soy broth (TSB) and was used as a positive control for peroxynitrite killing.

Chemicals. SNAP and SIN-1 were obtained from Alexis Corporation (San Diego, CA). Both chemicals were used according to the instructions provided by the supplier. All solutions were freshly prepared before each experiment and used immediately. N-acetylpenicillamine, the parental compound of SNAP which does not release NO, was used as a control at $1 \mathrm{mM}$.

Bactericidal assay. Bacteria were taken from the culture media, counted and suspended in Mueller-Hinton broth at $1 \times 10^{9}$ cells ml ${ }^{-1}$ (Renibacterium salmoninarum) or in TSB at $1 \times 10^{6}$ cells ml $^{-1}$ (Aeromonas salmonicida and Yersinia ruckeri). Starting concentrations for $R$. salmoninarum were higher due to the slow growth characteristic of the species. SNAP and SIN-1 were then added in serial dilutions from 0 to $1 \mathrm{mM}$ (Brunelli et al. 1995, Fierro et al. 1996). A total of $100 \mathrm{ml}$ of the bacterial suspension plus NO donors were pipetted into 96 -well plates in quadruplicate wells per dilution. An incubation period of $24 \mathrm{~h}$ was chosen for comparative purposes with a macrophage bactericidal assay against $R$. salmoninarum (CamposPérez 1998). After the incubation period, bacteria were centrifuged $(150 \times g)$, washed twice and allowed to grow for $7 \mathrm{~d}(R$. salmoninarum) or $24 \mathrm{~h}$ (A. salmonicida and Y. ruckeri). Superoxide dismutase (SOD, $300 \mathrm{U}$ $\mathrm{ml}^{-1}$ ) alone or with catalase (Cat, $300 \mu \mathrm{g} \mathrm{ml}^{-1}$ ) were added to some of the wells containing SIN-1. After the incubation period, $10 \mathrm{ml}$ of 3-(4,5-dimethylthiazol-2-yl) -2-5-diphenyltetrazolium bromide (MTT) solution at $5 \mathrm{mg} \mathrm{ml}^{-1}$ distilled water were added per well (Secombes 1990). Plates were read 15 min later in a multiscan spectrophotometer at $600 \mathrm{nM}$. The percentage of bacterial survival was calculated as:

$$
\frac{\text { OD treated wells }}{\text { OD untreated wells }} \times 100
$$

where OD = optical density.

\section{RESULTS}

\section{Cell-free NO toxicity}

SNAP was inhibitory for all species and strains tested. All Renibacterium salmoninarum strains except MT 1729 showed a decrease in growth of between 35 and $40 \%$ at the highest SNAP concentration, compared to non-treated controls (Fig. 1), with a significant $(p<0.001)$ dose effect being apparent. No significant differences were found between strains MT 426, MT 405 and MT 251. However, the virulent strain MT 1729 


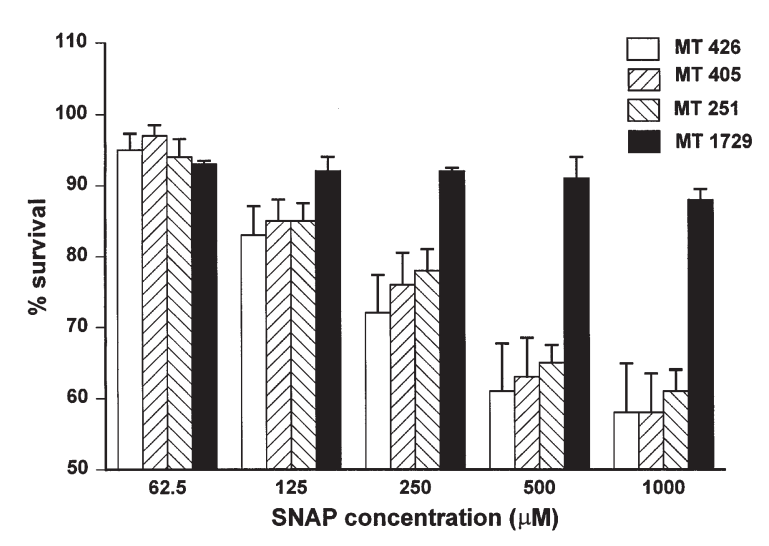

Fig. 1. Effect of SNAP on strains of Renibacterium salmoninarum. Bars represent mean $+\mathrm{SE}$ of 3 separate experiments

showed a higher growth which was significant ( $\mathrm{p}<$ 0.001) compared to the other strains. MT 1729 showed only $10 \%$ inhibition at the highest SNAP concentration, and no significant dose effect was found. The Aeromonas salmonicida strains also showed a significant dose effect $(p<0.001)$ in their susceptibility to SNAP, though no significant differences were found between strain MT 004 and MT 423 (Fig. 2). By comparison, Yersinia ruckeri was relatively resistant to NO inhibition, showing less than $25 \%$ decrease in growth even at the highest SNAP concentration (Fig. 2). However, the inhibition did show a significant $(\mathrm{p}<0.05)$ dose effect. No strain was inhibited when incubated with $1 \mathrm{mM} \mathrm{N}$-acetyl-penicillamine (data not shown).

\section{Cell-free peroxynitrite toxicity}

SIN-1 alone was not inhibitory for Renibacterium salmoninarum and the results from these experiments were the same for all 4 strains tested. The data shown in Fig. 3 for strain MT 251 are representative of all the

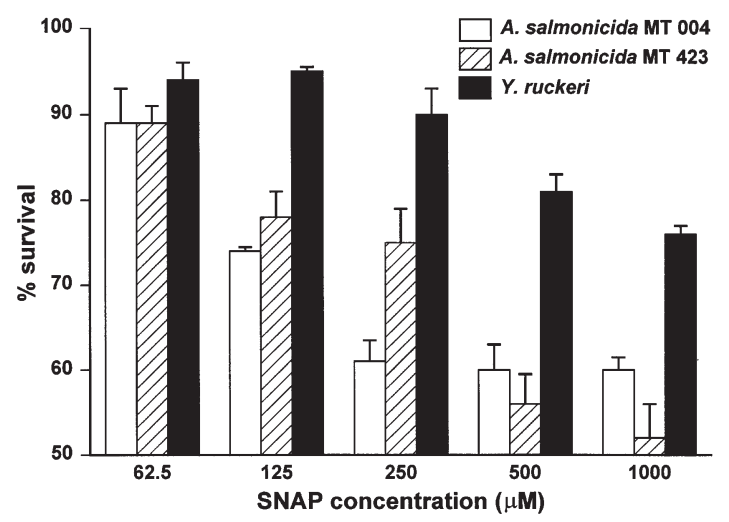

Fig. 2. Effect of SNAP on Aeromonas salmonicida and Yersinia ruckeri. Bars represent mean + SE of 3 separate experiments

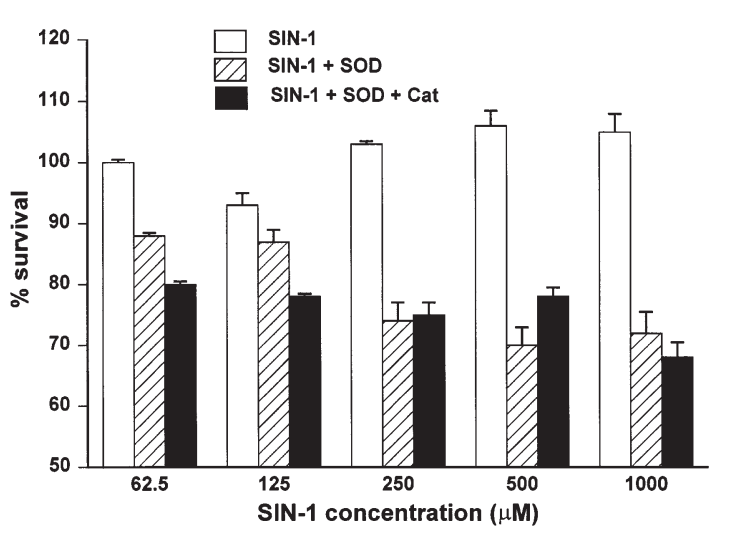

Fig. 3. Effect of SIN-1 on Renibacterium samoninarum MT 251. Bars represent mean $+\mathrm{SE}$ of 3 separate experiments

strains. Interestingly, when SOD alone or in combination with catalase was added, a significant $(p<0.001)$ dose-related inhibitory effect was seen and this effect was not very different to that seen with SNAP. The fact that the inhibition caused by SOD in combination with catalase showed no statistical differences compared to that by SOD alone suggests that hydrogen peroxide was not involved in the inhibitory effect. Furthermore, hydrogen peroxide has not been detected during SIN-1 decomposition at the same concentrations used here (Brunelli et al. 1995). Aeromonas salmonicida MT 004 showed a slight susceptibility to SIN-1, although no significant dose effect was apparent, with approximately $15 \%$ decrease in growth at the highest dose (Fig. 4). Interestingly, this strain showed about $100 \%$ growth when SOD was added to SIN-1, which was significantly $(\mathrm{p}<0.05)$ higher than SIN-1 alone. This strain also showed a slight but non-significant decrease in growth when catalase was added together with SOD. A. salmonicida strain MT 423 showed a pattern similar to that seen for $R$. salmoninarum (Fig. 5). SIN-1 alone did not show inhibitory effects, but after

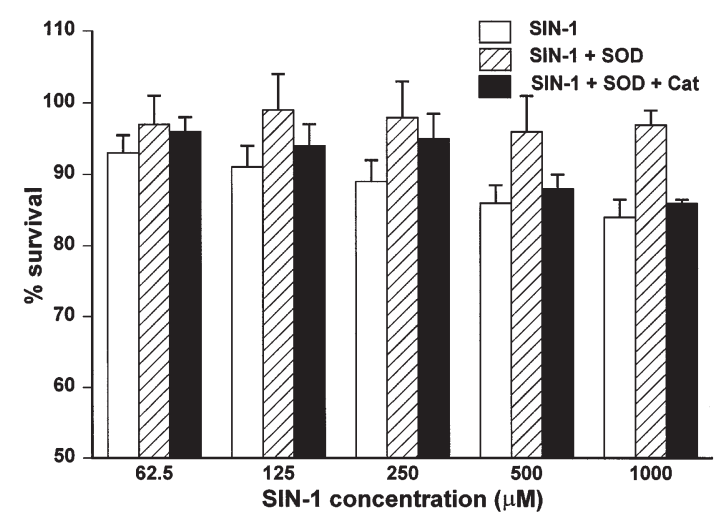

Fig. 4. Effect of SIN-1 on Aeromonas salmonicida MT 004. Bars represent mean $+\mathrm{SE}$ of 3 separate experiments 


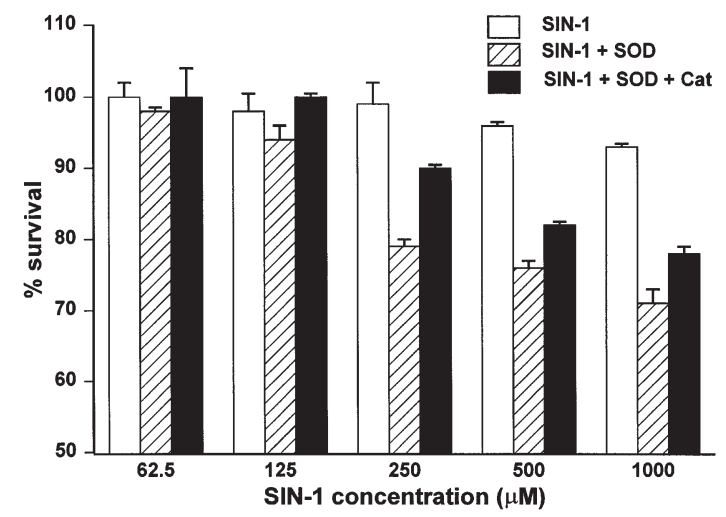

Fig. 5. Effect of SIN-1 on Aeromonas salmonicida strain MT 423. Bars represent mean + SE of 2 separate experiments

adding SOD, a significant $(p<0.001)$ dose-effect decrease in growth was apparent. Addition of catalase slightly decreased the inhibition seen with SIN-1 + SOD, though there was still a significant $(p<0.001)$ dose-effect. Escherichia coli, however, showed a doserelated inhibitory effect which was significant $(\mathrm{p}<$ 0.001) (Fig. 6), and this occurred under conditions identical to those used for the other bacterial species. $E$. coli has been reported to be peroxynitrite sensitive (Brunelli et al. 1995) and hence it was used as a positive control.

\section{DISCUSSION}

It has recently been shown that fish macrophages possess the inducible form of NOS, and that they are able to release NO after stimulation with certain molecules (Wang et al. 1995, Laing et al. 1999). The first experiments carried out to compare the bactericidal properties of $\mathrm{NO}$ and peroxynitrite suggested the latter molecule possessed a higher toxicity than NO for

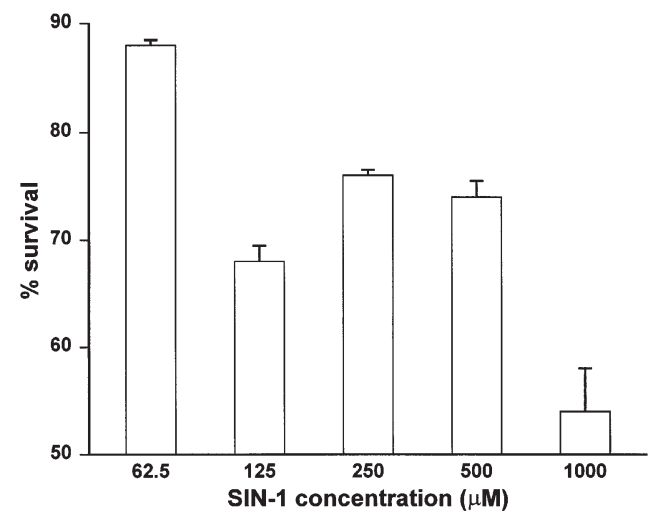

Fig. 6. Effect of SIN-1 on Escherichia coli. Bars represent mean $+\mathrm{SE}$ of 2 separate experiments
Escherichia coli (Brunelli et al. 1995, using SIN-1 and gaseous NO), Candida albicans (Vazquez-Torres et al. 1995, 1996, using SIN-1 and chemically synthesized peroxynitrite and sodium nitroprusside as NO generator) and Brugia malayi (Thomas et al. 1997, using SIN-1 and SNAP). Other authors, however, found the opposite situation to be true, with peroxynitrite showing some toxic effect, but the killing by NO alone being much higher for Leishmania major (Assreuy et al. 1994) and C. albicans (Fierro et al. 1996). In both studies SNAP and SIN-1 were used as generators and, interestingly, when SOD was added in combination with SIN-1, the inhibitory effect was significantly enhanced. The present results with a range of fish pathogens agree with these observations, although a difference was apparent, namely that no inhibition at all was seen using SIN-1. Furthermore, Kaplan et al. (1996) showed that SNAP-generated NO slightly impaired Staphylococcus aureus killing by $\mathrm{O}_{2}^{-}$at early time points ( 1 to $5 \mathrm{~h}$ ) following exposure. At later time points $(24 \mathrm{~h})$, exposure to NO correlated with decreased staphylococcal survival. The authors suggested that NO may be more useful under conditions when ROI release is compromised.

Studies of mammalian pathogens show that bacterial species depend on different mechanisms to protect themselves against RNI. Nagata et al. (1998) found that NO inhibits the respiration of Escherichia coli in a reversible fashion, whereas peroxynitrite also inhibits $E$. coli respiration but the effect is irreversible. In contrast, both compounds irreversibly inhibit the respiration of Helicobacter pylori. The authors hypothesised that NO reacted with endogenous superoxide radicals in $H$. pylori, resulting in peroxynitrite-mediated killing. Membrillo-Hernandez et al. (1999) have found evidence that upregulation of E. coli flavohemoglobin (as produced when in contact with NO releasing agents) plays a role in protection involving detoxification of NO-related species and sensing of oxidative stress. Other species of bacteria pathogenic to mammals are also known to express a range of enzymes and proteins which are associated with protection against RNI: Salmonella typhimurium lacking glucose 6-phosphate dehydrogenase (G6PD) are more susceptible to ROI and RNI (Lundberg et al. 1999), and a role of flavohemoglobins in protection against RNI has also been suggested (Crawford \& Goldberg 1998a,b). Exposure of Mycobacterium tuberculosis to a series of NO donors (including SNAP) induced the synthesis of a heat shock protein, sHsp16 (Garbe et al. 1999). Interestingly, SIN-1 failed to produce a pattern consistent with differential gene expression. Unfortunately, there is a paucity of information about the production of enzymes and proteins by fish bacterial pathogens under oxidative stress by RNI compared to mammalian 
microbes. Hence, the study of the proteins produced under oxidative stress and the effect of RNI in mutants lacking the genes which produce such proteins would help to identify the mechanisms used by fish pathogens to protect themselves from NO and NO derivatives.

In spite of the lack of information, it is tempting to speculate that the apparent resistance to NO of Renibacterium salmoninarum MT 1729 is due to some protective effect caused by the presence of the p57 protein. The presence of this protein is correlated with autoaggregation and virulence (Bruno 1988, 1990) and with immunosuppression (Wood \& Kaattari 1996). Moreover, it is a potent inhibitor of the respiratory burst (Densmore et al. 1998). The p57 is not known to possess protective properties but the A-layer of Aeromonas salmonicida is also correlated with virulence and protection against the products of the respiratory burst (Karczewski et al. 1991). Why Yersinia ruckeri is less susceptible to inhibition by NO is less clear, although the species is known to be a facultative anaerobe, and James (1995) has suggested that some parasites may switch from aerobic to anaerobic metabolism to avoid dependence on enzymes which may be deactivated by NO.

The inhibition seen when SOD was added to the SIN-1 system may be the result of 1 of 2 possible scenarios: CuZnSOD does not bind NO (Gorren et al. 1987) and so remains capable of scavenging $\mathrm{O}_{2}^{-}$. In the absence of $\mathrm{O}_{2}^{-}$the half life of NO may be enhanced, preserving its reactivity and toxic effects (Oury et al. 1992). Thus, the normal half life of NO (4 to 50 s) may be prolonged, allowing it to reach molecules deep in the target cell. The second possibility is that, if the exogenous SOD contains $\mathrm{Cu}$, peroxynitrite will react with it to form a potent nitrating agent with the reactivity of a nitronium ion $\left(\mathrm{NO}_{2}{ }^{+}\right)$which nitrates tyrosine residues (Beckman \& Crow 1993). In cells, this results in impairment of intracellular signal transduction (Berlett et al. 1996). Why Aeromonas salmonicida MT 004 showed an increased growth when exposed to SIN-1 and SOD is not clear, as this strain has been reported to be susceptible to oxygen radicals (Karczewski et al. 1991). However, it has been shown that when A. salmonicida is exposed to low concentrations of hydrogen peroxide the bacterium expresses a periplasmic MnSOD and increased levels of cytoplasmic catalase, conferring resistance to ROS (Barnes et al. 1999). MnSOD has been related to protection against SNAP-produced NO (Sano et al. 1997). This may explain the apparent resistance of strain MT 004 to inhibition by SIN-1 in the presence of SOD, which would generate hydrogen peroxide from the $\mathrm{O}_{2}^{-}$, which in turn may have induced the expression of MnSOD and catalase.
The results shown here do not differentiate if the effect seen is bactericidal or bacteriostatic. However, the fact that all bacterial species and strains tested were susceptible to SNAP shows that NO itself is a potent inhibitory agent and its potential value in an in vivo situation is supported by the fact that the final product of $\mathrm{NO}$ decomposition is mainly $\mathrm{NO}_{2}{ }^{-}$. $\mathrm{NO}_{2}{ }^{-}$can be converted back to active NO by dismutation at low pH (Stuehr \& Nathan 1989), as present in a phagocytic vacuole inside a macrophage. In this acidic environment NO would be much more effective than peroxynitrite, which decays to form $\mathrm{NO}_{3}^{-}$, in a reaction accelerated at an acidic $\mathrm{pH}$ decreasing the toxicity of peroxynitrite (Zhu et al. 1992). Moreover, NO kept inside these phagocytic vacuoles may accumulate until it reaches the concentration required to produce bacterial killing (Chan et al. 1992).

Finally, in several in vitro models of macrophage bactericidal activity it has been shown that while producing NO the killing capacity of macrophages was not affected when SOD was added to the system (Denis 1991, Chan et al. 1992). Interestingly, the microorganisms used in these studies were intracellular pathogens of the genus Mycobacterium. This further supports the notion that, for intracellular bacteria, $\mathrm{O}_{2}{ }^{-}$ has no part in the inhibitory effect and that peroxynitrite may not be involved. Put together, the present data suggest that, while peroxynitrite formation is inhibitory for certain species of microbes, the fish pathogens used in the present study appear to be more susceptible to NO alone, with the acidic environment of intracellular vacuoles possibly favouring its inhibitory action.

Acknowledgements. J.J.C.-P. would like to thank the Consejo Nacional para la Ciencia y la Tecnología (CONACYT) of Mexico for a PhD grant.

\section{LITERATURE CITED}

Assreuy J, Cunha FQ, Epperlein M, Noronha-Dutra A, O'Donnell CA, Liew FY, Moncada S (1994) Production of nitric oxide and superoxide by activated macrophages and killing of Leishmania major. Eur J Immunol 24:672-676

Barnes AC, Bowden TJ, Horne MT, Ellis AE (1999) Peroxideinducible catalase in Aeromonas salmonincida subsp. salmonicida protects against exogenous hydrogen peroxide and killing by activated rainbow trout, Oncorhynchus mykiss L., macrophages. Microb Pathogen 26:149-158

Beckman JS, Crow JP (1993) Pathological implications of nitric oxide, superoxide and peroxynitrite formation. Biochem Soc Trans 21:330-334

Berlett BS, Friguet B, Yim MB, Chock PB, Stadtman ER (1996) Peroxynitrite-mediated nitration of tyrosine residues in Escherichia coli glutamine synthetase mimics adenyllylation: relevance to signal transduction. Proc Natl Acad Sci USA 93:1776-1780

Brunelli L, Crow JP, Beckman JS (1995) The comparative tox- 
icity of nitric oxide and peroxynitrite to Escherichia coli. Arch Biochem Biophys 316:327-334

Bruno DW (1988) The relationship between agglutination, cell surface hydrophobicity and virulence of the fish pathogen, Renibacterium salmoninarum. FEMS Microbiol Lett 51: 135-140

Bruno DW (1990) Presence of a saline extractable protein associated with virulent strains of the fish pathogen Renibacterium salmoninarum. Bull Eur Assoc Fish Pathol 10: $8-10$

Buentello JA, Gatlin DM III (1999) Nitric oxide production in activated macrophages from channel catfish (Ictalurus punctatus): influence of dietary arginine and culture media. Aquaculture 179:513-521

Campos-Pérez JJ (1998) The role of reactive oxygen and nitrogen species in the immune response of rainbow trout against Renibacterium salmoninarum. $\mathrm{PhD}$ thesis, University of Aberdeen

Campos-Pérez JJ, Ward MP, Grabowski PS, Ellis AE, Secombes CJ (2000) The gills are an important site of iNOS expression in rainbow trout Oncorhynchus mykiss after challenge with the Gram-positive pathogen Renibacterium salmoninarum. Immunology 99:153-161

Carreras MC, Pargament GA, Catz SD, Poderoso JJ, Boveris A (1994) Kinetics of nitric oxide and hydrogen peroxide production and formation of peroxynitrite during the respiratory burst of human neutrophils. FEBS Microbiol Lett 341:65-68

Chan J, Xing Y, Magliozzo RS, Bloom B (1992) Killing of virulent Mycobacterium tuberculosis by reactive nitrogen intermediates produced by activated macrophages. J Exp Med 175:1111-1122

Clark IA, Rockett KA (1996) Nitric oxide and parasitic disease. Adv Parasitol 37:1-56

Crawford MJ, Goldberg DE (1998a) Role for the Salmonella flavohemoglobin in protection from nitric oxide. J Biol Chem 273:12543-12547

Crawford MJ, Goldberg DE (1998b) Regulation of the Salmonella typhimurium flavohemoglobin gene. A new pathway for bacterial gene expression in response to nitric oxide. J Biol Chem 273:34028-34032

Denicola A, Rubbo H, Rodriguez D, Radi R (1993) Peroxynitrite-mediated cytotoxicity to Trypanosoma cruzi. Arch Biochem Biophys 304:279-286

Denis M (1991) Interferon-gamma-treated murine macrophages inhibit growth of tubercle bacilli via the generation of reactive nitrogen intermediates. Cell Immunol 132: 150-157

Densmore CL, Smith SA, Holladay SD (1998) In vitro effects of the extracellular protein of Renibacterium salmoninarum on phagocyte function in brook trout. Vet Immunol Immunopathol 62:349-357

Doi T, Ando M, Akaike T, Suga M, Sato K, Maeda H (1993) Resistance to nitric oxide in Mycobacterium avium complex and its implication in pathogenesis. Infect Immun 61: 1980-1989

Drapier JC, Hibbs JB (1988) Differentiation of murine macrophages to express nonspecific cytotoxixity for tumor cells results in L-arginine-dependent inhibition of mitochondrial iron-sulfur enzymes in the macrophage effector cells. J Immunol 140:2829-2838

Fierro IM, Barja-Fidalgo C, Cunha FQ, Ferreira SH (1996) The involvement of nitric oxide in the anti-Candida albicans activity of rat neutrophils. Immunology 89:295-300

Forman LJ, Liu P, Nagele RG, Yin K, Wong PYK (1998) Augmentation of nitric oxide, superoxide and peroxynitrite production during cerebral ischemia and reperfusion in the rat. Neurochem Res 23:141-148

Garbe TR, Hibler NS, Deretic V (1999) Response to reactive nitrogen intermediates in Mycobacterium tuberculosis: induction of the 16-kilodalton alpha-crystallin homolog by exposure to nitric oxide donors. Infect Immun 67:460-465

Gorren AC, De Boer E, Wever R (1987) The reaction of nitric oxide with copper proteins and the photodissociation of copper-NO complexes. Biochem Biophys Acta 916:38-47

Hyman MR, Arp DJ (1991) Kinetic analysis of the interaction of nitric oxide with the membrane-associated, nickel and iron-sulfur-containing hydrogenase from Azotobacter vinelandii. Biochem Biophys Acta 1076:165-172

Ischiropoulos H, Zhu L, Beckman JS (1992) Peroxynitrite formation from macrophage-derived nitric oxide. Arch Biochem Biophys 298:446-451

James SL (1995) Role of nitric oxide in parasitic infections. Microbiol Rev 59:533-547

Kahl R, Wulff U, Netter KJ (1978) Effect of nitrite on microsomal cytochrome P450. Xenobiotica 8:359-364

Kaplan SS, Lancaster JR, Basford RE, Simmons RL (1996) Effect of nitric oxide on staphylococcal killing and interactive effect with superoxide. Infect Immun 64:69-76

Karczewski JM, Sharp GJE, Secombes CJ (1991) Susceptibility of strains of Aeromonas salmonicida to killing by cellfree generated superoxide anion. J Fish Dis 14:367-373

Laing KJ, Aartsen W, Grabowski PS, Secombes CJ (1999) Expression of an inducible nitric oxide synthase gene in rainbow trout Oncorhynchus mykiss. Dev Comp Immunol 23:71-85

Lepoivre M, Fieschi F, Coves J, Thelander L, Fontecave M (1991) Inactivation of ribonucleotide reductase by nitric oxide. Biochem Biophys Res Commun 179:442-448

Lundberg BE, Wolf RE, Dinauer MC, Xu Y, Fang FC (1999) Glucose 6-phosphate dehydrogenase is required for Salmonella typhimurium virulence and resisitance to reactive oxygen and nitrogen intermadiates. Infect Immun 67: $436-438$

Membrillo-Hernandez J, Coopamah MD, Anjum MF, Stevanin TM, Kelly A, Hughes MN, Poole RK (1999) The flavohemoglobin of Escherichia coli confers resistance to a nitrosating agent, a 'nitric oxide releaser' and paraquat and is essential for transcriptional responses to oxidative stress. J Biol Chem 274:748-754

Nagata K, Yu H, Nishikawa M, Kashiba M, Nakamura A, Sato EF, Tamura T, Inoue M (1998) Helicobacter pylori generates superoxide radicals and modulates nitric oxide metabolism. J Biol Chem 273:14071-14073

Neumann NF, Belosevic M (1996) Deactivation of primed respiratory burst response of goldfish macrophages by leukocyte-derived macrophage activating factor(s). Dev Comp Immunol 20:427-439

Neumann NF, Fagan D, Belosevic M (1995) Macrophage activating factor(s) secreted by mitogen stimulated goldfish kidney leukocytes synergize with bacterial lipopolysaccharide to induce nitric oxide production in teleost macrophages. Dev Comp Immunol 19:473-482

O'Brien L, Carmichel J, Lowrie DB, Andrew PW (1994) Strains of Mycobacterium tuberculosis differ in susceptibility to reactive nitrogen intermediates in vitro. Infect Immun 62:5187-5190

Oury TD, Ho YS, Piantadosi CA, Crapo JD (1992) Extracellular superoxide dismutase, nitric oxide, and central nervous system $\mathrm{O}_{2}$ toxicity. Proc Natl Acad Sci USA 89:9715-9719

Rhoades ER, Orme IM (1997) Susceptibility of a panel of virulent strains of Mycobacterium tuberculosis to reactive nitrogen intermediates. Infect Immun 65:1189-1195

Sano H, Hirai M, Saito H, Nakashima I, Isobe KI (1997) A 
nitric oxide-releasing reagent, S-nitroso-N-acetylpenicillamine, enhances the expression of superoxide dismutases mRNA in murine macrophage cell line RAW264-7, Immunology 92:118-122

Schoor WP, Plumb JA (1994) Indication of nitric oxide syntahse in channel catfish Ictalurus punctatus by Edwarsiella ictaluri. Dis Aquat Org 19:153-155

Secombes CJ (1990) Isolation of fish macrophages and analysis of their killing activity. In: Stolen JS, Fletcher TC, Anderson DP, Robertson BS, van Muiswinkel WB (eds) Techniques in fish immunology. SOS publications, Fair Haven, NJ, p 137-154

Sharp GJE, Secombes CJ (1993) The role of reactive oxygen species in the killing of the bacterial fish pathogen Aeromonas salmonicida by rainbow trout macrophages. Fish Shellfish Immunol 3:119-129

Shimojo T, Nishikawa T, Ishiyama S, Ikeda I, Kasajima T, Marumo F, Hiroe M (1998) Participation of nitric oxide and peroxynitrite in the development of myocardial tissue damage in acute myocardial infarction. Cardiovasc Pathol $7: 25-30$

Soderstrom V, Hylland P, Nilsson GE (1995) Nitric oxide synthase inhibitor blocks acetylcholine induced increase in brain blood flow in rainbow trout. Neurosci Lett 197: 191-194

Stuehr DJ, Nathan CF (1989) Nitric oxide: a macrophage product responsible for cytostasis and respiratory inhibition in tumor target cells. J Exp Med 169:1543-1555

Szabo C, O'Connor M, Salzman AL (1997) Endogenously produced peroxynitrite induces the oxidation of mitochondrial and nuclear proteins in immunostimulated macrophages. FEBS Microbiol Lett 409:147-150

Thomas GR, McCrossan M, Selkirk ME (1997) Cytostatic and

Editorial responsibility: David Bruno,

Aberdeen, Scotland, UK cytotoxic effects of activated macrophages and nitric oxide donors on Brugia malayi. Infect Immun 65:2732-2739

Vazquez-Torres A, Jones-Carson J, Balish E (1995) Nitric oxide production does not directly increase macrophage candidacidal activity. Infect Immun 63:1142-1144

Vazquez-Torres A, Jones-Carson J, Balish E (1996) Peroxynitrite contributes to the candidacidal activity of nitric oxideproducing macrophages. Infect Immun 64:3127-3133

Wang PH, Zweier JL (1996) Measurement of nitric oxide and peroxynitrite generation in the postischemic heart-evidence for peroxynitrite-mediated reperfusion injury. J Biol Chem 271:29223-29230

Wang R, Neumann NF, Shen Q, Belosevic M (1995) Establishment and characterisation of a macrophage cell line from goldfish. Fish Shellfish Immunol 5:329-346

Wiegertjes GF, Saeij JPJ, Mossnik MH, Regeer RR, Stet RJM (1998) Immunogenetic resistance to the parasitic protozooan Trypanoplasma borreli in carp (Cyprinus carpio L.). The 4 th nordic symposium on fish immunology abstracts. Hirtshals

Wink DA, Osawa Y, Darbyshire JF, Jones CR, Eshenaur SC, Nims RW (1993) Inhibition of cytochromes-P450 by nitric oxide and a nitric oxide-releasing agent. Arch Biochem Biophys 300:115-123

Wong HY, Fung LY, Kwok F, Lo SCL (1998) Constitutive nitric oxide synthase (NOS) activities in big-head carp (Aristichthys nobilis). Fish Physiol Biochem 19:171-179

Wood PA, Kaattari SL (1996) Enhanced immunogenicity of Renibacterium salmoninarum in chinook salmon after removal of the bacterial cell surface-associated $57 \mathrm{kDa}$ protein. Dis Aquat Org 25:71-79

Zhu L, Gunn C, Beckman JS (1992) Bactericidal activity of peroxynitrite. Arch Biochem Biophys 298:452-457

Submitted: November 16, 1999; Accepted: July 28, 2000

Proofs received from author(s): October 23, 2000 